\title{
Current perspectives on the capabilities of high resolution XRF core scanners
} lan W. Croudace ${ }^{1}$, Ludvig Löwemark ${ }^{2}$, Rik Tjallingii ${ }^{3}$, Bernd Zolitschka ${ }^{4}$

${ }^{1}$ GAU-Radioanalytical, University of Southampton, National Oceanography Centre, Southampton, SO14 3ZH, United Kingdom

2 Department of Geosciences, National Taiwan University, P.O. Box 13-318, 106 Taipei, Taiwan

${ }^{3}$ GFZ German Research Centre for Geosciences, Telegrafenberg, 14473 Potsdam, Germany

${ }^{4}$ University of Bremen, Institute of Geography, Celsiusstr. 2, D-28359 Bremen, Germany

\begin{abstract}
The introduction and application of high resolution XRF core scanners has made an enormous contribution to palaeoclimate science over the last two decades. These core scanners have become essential analytical tools for the investigation of sedimentary and other natural cumulative records of environmental change. Their widespread adoption by the environmental and geoscience communities has had a significant impact on the ability to systematically record high resolution chemical profiles in marine and lake sediments and soils. The range of applications has broadened beyond sedimentology and palaeoclimatology and now extends into scanning samples of speleothems, corals, mumiyo mounds, rocks, sedimentary nodules, archaeological artefacts, tree sections and melt segregations. Other areas exploiting the capability of XRF core scanners are mineral exploration, geotechnical characterisation, soil remediation studies and carbon capture and storage research. As a consequence of their ability to efficiently determine detailed, non-destructive elemental records in sediments and soils, scientific papers published since the year 2000 now number more than 1000.
\end{abstract}

Keywords: XRF core scanner; high resolution analysis; non-destructive analysis; $\mu$ XRF analysis; palaeoclimate

\section{Introduction}

International scientific interest in XRF core scanners was triggered by the rapid expansion in palaeoclimate research from 2000 onward and the arrival of two commercial high resolution core scanner (CS) systems based on prototypes that originated in European marine research institutions. These instruments, the Avaatech-CS (The Netherlands) and the Itrax-CS (Southampton and Sweden) received a significant international launch at the 'New Techniques in Sediment Core Analysis' Conference held in Southampton in September 2003. Proceedings of the Conference, including four papers on the capabilities of the two core scanners, were later published in a Geological Society of London Special Publication (Croudace et al, 2006; Rothwell et al 2006; Thomson et al, 2006; Richter et al 2006). After a decade, other manufacturers also contributed to the range of capable XRF core scanner systems (Geotek in 2009; Bruker in 2012; Minalyze in 2014). The impact of these instruments have been presented in a series of international workshops that were largely instrument specific. By 
2017, there was broad interest in drawing all the different core scanner communities together for the 'XRF Core Scanning 2017' Conference (Taipei, 2017) that led to this Quaternary International Special Issue (Table 1). Since their first commercial appearance in 2003, the investigation of sediment cores and other records by XRF core scanners have led to more than 1000 papers in the scientific literature as well as two specialist books (Rothwell, 2006 and Croudace and Rothwell 2015) and now a Quaternary International Special Issue.

Non-destructive, high resolution XRF core scanners undoubtedly led to an advance in the acquisition of detailed down-core elemental profiles of sediments (Jansen et al 1998, Croudace et al 2006, Richter et al 2006, Rothwell and Croudace 2015). Most established instruments were designed to scan in a down-core linear mode (1D) but smaller, efficient, highly capable XRF X-Y mapping systems (2D) are now available (e.g. Bruker M4 Tornado). The XRF core scanners initially developed were optimised for studying layered sediment but they can be used to study elemental variations in almost any natural or synthetic solid system. The success of the technology is exemplified by the fact that there are now well over one hundred XRF core scanners globally distributed among many leading international research institutions. These powerful instruments enable automated analyses to be made efficiently and rapidly on virtually any solid with little sample preparation and at sediment layer resolutions down to sub-annual intervals. The key requirement for an effective investigation is scanning of a flat analytical surface to enable determination of elements from $\mathrm{Mg}$ through $\mathrm{U}$. The highest sensitivity for the lowest $\mathrm{Z}$ element ( $\mathrm{Na}, \mathrm{Mg}$ and $\mathrm{Al}$ ) depends significantly on the X-ray tube used for excitation and whether a helium path (for wet sediment) or a vacuum (for impregnated sediment) are used. Continued important technological improvements to detection systems now allow a high resolution elemental record to be acquired for a $1 \mathrm{~m}$-long core in a few hours compared with the situation a decade ago where $24-48$ hours was typical for a full trace and major element scan.

The arrival of non-destructive, high resolution, automatic XRF core scanning technology in the early 2000s introduced a crucial new tool for palaeoclimate researchers. Most early work was carried out in oceanographic laboratories studying marine sediments but interest quickly transitioned to include research institutions studying lake sediment. The early iconic research on finely laminated marine sediments from the anoxic Cariaco Basin demonstrated the huge capability of XRF core-scanners. These studies showed the ability of core scanners to identify the impact of hydrological cycles during the last glacial period (Peterson et al., 2000). The developments were initially stimulated by the increasing interest in studying high resolution elemental records as proxies for Holocene variability of the ITCZ (Haug et al., 2001) and relating the collapse of the Mayan civilization to climatic impact (Haug et al., 2003). Even at this early stage, the capability of the nondestructive X-ray technique, in combination with additional scanning methods, such as digital 
imagery, gamma-ray density, P-wave velocity and magnetic susceptibility, was clear (Röhl and Abrams, 2000). It was also noted by Zolitschka et al. (2001) that when applied to lake sediment cores, these techniques supported a new field that required rapid acquisition of analytical data to provide the time resolution necessary for new insights into palaeoeclimatic variability and their forcing factors.

The growing acquisition of high resolution XRF core scanner technology by the geoscience community has led to an almost exponential growth in publications and there are currently around 1000 scientific papers published in high impact journals. This paper, introduces the Special Issue on High Resolution XRF Core Scanners (Table 1 NEAR HERE) presents insights into the historical development of XRF core scanning systems, as well as examples of recent environmental applications (Figure 1; Figure 2 NEAR HERE) and calibration approaches. It also presents an overview of the study of finely laminated lacustrine sediments (seasonal couplets) that currently represent one of the most active areas of application of XRF core scanner technologies

\section{Historical evolution of high resolution XRF scanners}

Avaatech: The CORTEX (Corescanner Texel) developed at the Royal Netherlands Institute of Sea Research (NIOZ) in the late 1990s (Jansen et al 1998) and was the first X-ray core scanning system. The instrument continues to evolve and current instruments still uses a low power $\mathrm{X}$-ray tube and a slit collimation system. Initially built to support shipboard measurements, the instrument was used for a broad range of high resolution palaeoceanographic and sedimentological research, e.g. smallscale orbital and sub-orbital features preserved in sediment sequences. There are currently over thirty Avaatech-CS systems worldwide.

Itrax: The second XRF core scanner was the prototype Itrax-CS. This was originally conceived in the year 2000 by lan Croudace in Southampton who recognised the scientific potential for a single instrument that integrated a high-power X-ray tube (up to $3 \mathrm{~kW}$ ) with a $200 \mu \mathrm{m}$ X-ray capillary wave guide, an X-radiography system and an optical camera to enable co-registration of high resolution elemental, visual and density/textural data. With colleagues G. Rothwell and J. Thomson (Croudace et al, 2006; Rothwell et al, 2006; Thomson et al, 2006) and research funding from the UK Office of Science and Technology, a project was initiated that led to Cox Analytical Systems (Gothenburg, Sweden) being invited as technical partners. In early 2003, following a 15-month collaborative development, the prototype Itrax-CS was delivered to Southampton and was showcased at the New Techniques in Sediment Core Analysis Conference later in the same year. There are currently over fifty Itrax-CS systems worldwide and new models are now being added to the range. 
Tatscan: Two XRF core scanners were developed in Japan by Sakamoto and co-workers but their use was largely confined to Japan. A significant number of research publications (e.g. Sakamoto et al., 2006) arose from their use and one instrument was originally installed on the Research Vessel Chikyu.

Geotek: In 1990 Geotek launched the Multi-Sensor Core Logger (MSCL) an automated and nondestructive core scanning system by installing an instrument at the United States Geological Survey (USGS). The MSCL was developed to measure both physical and some geochemical parameters (Schultheiss et al., 1987). In 2009, the small integrated InnovX XRF instrument was added as an option onto the MSCL platform with later enhanced XRF variants being made available (Olympus Delta, Olympus Vanta). The system is argued to be a cost-effective entry level into XRF core scanning (Schillereff et al. 2015; Boyle et al, 2015). There are now over $250 \mathrm{MSCL}$ installations worldwide. In 2013 Geotek launched a compact, helium-flushed XRF sensor with claimed downcore resolutions of $0.1 \mathrm{~mm}$ coupled and good sensitivity for the light energy elements ( $\mathrm{Na}, \mathrm{Mg}, \mathrm{Al}$, and $\mathrm{Si})$.

Bruker M4 Tornado: Small bench-top micro-XRF systems designed for sample sizes of $10-20 \mathrm{~cm}$ have existed for ca. 20 years and were developed as a microanalytical tool for use in many sectors (geoscience, biomedical, materials, forensics, electronic etc). One of the most recently developed systems, that evolved from the EDAX Eagle III micro-XRF instrument (e.g. Haschke, 2006; Dulski et al., 2015). The M4 Tornado can investigate samples up to $19 \times 19 \mathrm{~cm}$ and has been applied to many sample types including detailed high resolution elemental mapping of impregnated sediment blocks taken from cores. These systems are equipped with capillary X-Ray waveguides to facilitate efficient excitation and high resolution spectral acquisition. However, with acquisition times of $>5 \mathrm{hrs} / \mathrm{mm}^{2}$ mapping of sediment surfaces was initially limited to the mapping of small sediment areas (Dulski et al., 2015). Progressive improvements in both X-ray source excitation and silicon-drift X-ray detectors (SDD devices) have reduced measurement times to $\sim 1 \mathrm{~min} / \mathrm{mm}^{2}$ (e.g. Bruker M4-Tornado), which allows elemental mapping of entire impregnated sediment blocks (ca. $100 \times 20 \mathrm{~mm}$ ) in only a few hours. These high resolution $x-y-z$ systems are ideally suited to the examination of small samples of impregnated, finely-laminated sediments and compete with modern SEM systems in terms of elemental mapping.

Minalyzer CS: This is a mobile, self-contained instrument designed mostly for non-destructive analysis of rock drill cores directly in core trays and was particularly directed at the metalliferous mining sector. Developed by Minalyze AB (Gothenburg, Sweden), the instrument was launched in 2015. Drill cores are optically documented by a high resolution colour camera and 3-D laser and scanned using a collimated beam from an X-ray tube operating up to $50 \mathrm{kV}$ and $24 \mathrm{~mA}$ to provide elemental data and sample density. Scanning paths are automatically defined from the 3-D laser topography and a robotic system executes the XRF analysis. Low-energy X-ray detection is facilitated 
by the use of a confined vacuum or helium atmosphere in front of the detector, thereby allowing analysis of elements as light as Mg. The 3-D data are also used to measure structural features such as cracks and joints with results being displayed in a cloud-based viewer (Sjöqvist et al 2015).

\section{Calibration and validation of XRF corescanner data}

The outstanding benefits of XRF core scanners are their ability to provide automatic, nondestructive, rapid and high resolution along core elemental analysis. The most common XRF scanner output applied by users are element intensity records (in counts or cps) produced by XRF scanning that are representative of variations in material chemical composition. The elemental output can, however, be adversely affected by physical effects such as non-flat, irregular, or cracked surfaces as well as by variations of the sample/sediment matrix (e.g. Jansen et al., 1998; Croudace et al., 2006; Tjallingii et al., 2007; Weltje et al., 2015). Apart from matrix effects, these variations are effectively eliminated by normalizing element intensities by calculating element ratios or proportions of a constant number of elements (e.g. Jansen et al., 1998; Croudace et al., 2006; Weltje and Tjallingii, 2008; Löwemark et al., 2011; Weltje et al. 2015). Matrix effects cause nonlinear absorption and enhancement of element intensities and are not effectively compensated by normalization (Weltje and Tjallingii, 2008). Unlike XRF analyses of discrete powder or glass bead samples, matrix effects cannot be quantified for XRF core scanning records due to highly variable nature of sediment properties down core. However, the log-ratio calibration model provides a solution via estimation of relative matrix effects. It has been demonstrated that log-ratios of XRF intensities are linearly related to log-ratios of geochemical concentrations (Weltje and Tjallingii, 2008; Weltje et al., 2015). Therefore, log-ratios of element intensities provide a linear solution for the interpretation of element intensity records in terms of chemical compositions by a simple transformation.

The development of the log-ratio calibration model provided a robust solution for quantification of XRF core scanning records and it is also consistent with the statistical theory of compositional data analyses (Aitchison, 1982; Weltje et al., 2015). Consequently, log-ratios of element intensities provide a reliable basis for statistical analysis of XRF core scanning data, unlike element count intensities or element ratios (Bloemsma, 2015; Weltje et al., 2015). Statistically robust uncertainty estimations need to be calculated using replicate measurements (three times or more) to indicate confidence limits of the measured element intensities (Weltje and Tjallingii, 2008). Statistical analysis based on log-ratios of XRF element intensity records offer a powerful tool to explore element correlations. Unlike data expressed as relative abundances (e.g. ppm, g/kg, wt\%), log-ratios do not suffer from the effects of constant-sum constraints (Aitchison, 1982). Therefore, log-ratio 
transformation of core data is free of intrinsic correlations and provides statistically reliable results (Weltje et al., 2015).

Visualization of statistically-robust core data provides a profound approach for the interpretation of element records acquired by XRF core scanning and validates these records in terms of environmental processes (e.g. inferring depositional environments). A bi-plot provides a graphical display of principal component analyses (PCA) that project both data distributions and element correlations (Aitchison and Greenacre, 2002). In the case of XRF data, the direction and length of the elements displayed in a bi-plot reveal the correlation and strength of the correlations, which helps to link the elements measured with the observed sediment fractions (e.g. Bloemsma, 2015; MartinPuertas et al., 2017; Ramisch et al., 2018). For instance, the bi-plot visualization of the EarlyHolocene varved sediments from Meerfelder Maar (Figure 3a NEAR HERE) reveal that these sediments mainly consist of detrital siliciclastics (inferred from $\mathrm{K}, \mathrm{Ti}$ ), redox-sensitive components (inferred from $\mathrm{Mn}, \mathrm{Fe}$ ) and carbonates (inferred from $\mathrm{Ca}, \mathrm{Sr}$ ).

Another statistical application for visualisation of similarities and differences of variables is provided by hierarchical clustering which divides the total data set into groups of similar compositions thereby helping establish geochemical boundaries for the sediment succession (Lengger et al., 2013; Bloemsma, 2015; Martin-Puertas et al., 2017). Although the number of clusters is not objectively selected objectively, grouping of the data into individual clusters is entirely based on statistical analyses and therefore free of subjectivity. Moreover, hierarchical clustering allows visualization of compositional differences and similarities in a stratigraphically unconstrained way and objective determination of lithological boundaries. Bi-plots of the individual clusters help to visualize compositional differences of these individual clusters for detailed information on the changes of the sediment compositions and of depositional environments. For example, the bi-plots of multivariate statistical clusters of the Early-Holocene varved sediments from Meerfelder Maar distinguish periods when $\mathrm{Si}$ is mainly bound to minerogenic matter from those where $\mathrm{Si}$ is driven by diatom concentrations (Figure 3b).

Further validation of XRF records and statistical analyses of core scanner data can be obtained by comparison with detailed observations and other proxy records. However, most destructive proxy records have sampling resolutions of typically $1-10 \mathrm{~mm}$ at best and make detailed comparison of XRF core scanning records with sampling resolutions of $<1 \mathrm{~mm}$ (finely laminated sediments) problematic. Such finely laminated sediments are typically studied using micro-XRF mapping of impregnated sediment blocks using scanning electron microscopic (SEM) methods or more recently the Bruker M4-Tornado micro-XRF. The potential of XRF mapping results is demonstrated by the results of two impregnated sediment blocks of the Early-Holocene varved sediments from Meerfelder Maar (Figure 3c). The XRF maps revealed a strict separation of diatom 
layers (inferred from Si) and siliciclastic detrital layers (inferred from Ti) during periods when $\mathrm{Si}$ is mainly bound to minerogenic matter (cluster 4), confirming the interpretation made by multivariate statistical analysis (Martin-Puertas et al. 2017).

The development of the log ratio-calibration model (Weltje and Tjallingii, 2008; Weltje et al., 2015) has provided a reliable and statistically robust way to use and interpret XRF element intensities. Combining the processing of XRF scanning records using log-ratios of element intensities, robust statistical analysis, detailed elemental mapping and microscopic observations of sediment textures and mineralogy all lead to improvement in the reconstruction of depositional environments and climatic reconstructions. Another promising development involves the reliable prediction of grain-size distributions from XRF core scanning data (Bloemsma et al., 2012). Overall, the application of multivariate statistical methods provides a potential for extracting quantitatively reliable records from XRF core scanning data.

\section{XRF core scanning and storm record in coastal marine sediments}

The identification of storm records in coastal sediment sequences is important for such areas as understanding pollution histories for regulatory agencies and in coastal zone risk management linked to major engineering projects. XRF core scanners represent a practical and efficient tool for non-destructively acquiring elemental profiles and radiographic information to support such investigations. The determination of long-term storm records in sediments is important as part of risk assessments where major engineering projects are planned (e.g. the new Hinkley Point PWR reactor site in the Bristol Channel).

XRF core scanning made a major contribution to an investigation of sub-tidal sediments from the Severn Estuary. The Estuary, well-known for its $15 \mathrm{~m}$ tidal range, is a component part of the large funnel-shaped Bristol Channel. The study was undertaken on behalf of the UK Environment Agency that was concerned about the impact of estuarine discharges of organically-bound tritium from a radiopharmaceutical site near Cardiff, UK (Figure 4; NEAR HERE, Croudace et al, 2012). The site operated mostly from 1982-2010. The investigation acquired radionuclide and geochemical data from sediment cores to understand the fate of the discharged radioactive compounds in the estuary. By combining geochemical (heavy metal pollution signals) and textural evidence (lithological and erosion features) with radiochronological indicators of sediment accumulation it was concluded that the complete OBT discharge record was preserved in the sediment cores. By contrast, however, industrial records of heavy metals $(\mathrm{Cu}, \mathrm{Zn}$ and $\mathrm{Pb})$ and atmospheric inputs of ${ }^{137} \mathrm{Cs}$ and ${ }^{210} \mathrm{~Pb}$ were significantly disrupted. Explaining the disrupted record required a major estuarine event. The Severn Estuary and Bristol Channel often receive the impact of strong westerlies and on December $13^{\text {th }} 1981$ an unusually fierce winter storm, coinciding with high tides, produced a 2 metre storm surge (near 
Newport) that led to significant erosion of intertidal areas but any impact on sub-tidal areas was unknown. The first evidence that the storm surge had caused significant sub-tidal erosion of sediment was found in a core that showed a storm pebble layer (Croudace et al., 2012). This occurred at the same position in the sediment core as major inflections in radiochronological and heavy metal data and showed that part of the sedimentary record was lost through erosion. This event occurred only months before the radiopharmaceutical site had begun its operations and discharges.

Another major storm surge led to significant coastal damage in low lying areas of countries bordering the southern North Sea in 1953. The Netherlands, Belgium and the UK were particularly badly impacted by the surge and more than 2000 people lost their lives. Studies of saltmarsh sediments at Wrangle and Holkham on the east coast of England aimed to determine if records of the storm surge were preserved in the stratigraphic record (Tsobanouglou et al, 2010; Swindles et al, 2018). Detailed sedimentological characterisation of the sediments, accompanied by Itrax core scanning and radiometric dating, were used to identify past storm surge deposits and the timing of past surge events. Such studies are important in determining the frequency and magnitude of storm surges which in turn inform coastal zone risk management.

\section{XRF core-scanning and lake sedimentary records}

In the absence of long instrumental records of climatic and environmental variabilities, XRF core scanner data can provide potentially powerful proxy records of environmental change. Their high resolution makes them ideally suited to detect climatic change such as hydroclimatic and erosional variability from millennial to sub-decadal time scales. In some cases, they are also excellent at detecting events via identification of products of storms, storm surges, volcanic eruptions, earthquakes and polar ice cover reflected through changes in mineralogy, elemental composition and texture.

Cultural eutrophication studies: Anthropogenically-induced eutrophication and pollution in lake sediments is widespread and can be magnified where the impacts of population, tourism and farming combine to promote algal production (e.g. Jenny et al 2016). A graphic example (Figure 5 NEAR HERE) is reported for sediment cores collected from Windermere (a seasonally stratified lake in the English Lake District National Park). The progressive rise in pastoral farming, agricultural runoff and human sewage inputs, along with early wastewater treatment, provided nutrients for the seasonal growth of algae leading to deposition of diatomaceous laminae. The uppermost sedimentary record is lithologically distinctive, being organic-rich (gyttja) with distinct heavy metal enrichments in the top $25 \mathrm{~cm}$ (representing a period from ca. 1850 to the present). Geochemical 
profiles of the sediment cores (measured by Itrax and WD-XRF) show a record of heavy metal enrichment (e.g. $\mathrm{Zn}, \mathrm{As}, \mathrm{Cu}, \mathrm{Pb}$ ). Microfabric and geochemical analyses (Figure 5) also demonstrate that diffusion of reduced mobile $\mathrm{Mn}$ and Fe occurred from the anoxic sediment and was precipitated at the redox boundary near the sediment-water interface (Fielding et al, 2019). Other geochemical data show enrichment of $\mathrm{Hg}$ and document that the $\mathrm{Pb}$ component (from 19301990) has a stable isotope composition dominated by leaded petrol (Miller et al, 2015).

Palaeoseismic studies: The sedimentary records in lakes and marine margins can incorporate mass transport deposits (MTDs) caused by slope-failures triggered by seismic activity (Gracia et al., 2013; Strasser et al., 2013). Lake sediments are established recorders of palaeoseismicity in seismically active regions but less tectonically-active areas may also host mass transport deposits (MTDs). One example reported by Fielding et al (2018) describes an Itrax-studied lacustrine sediment core from Windermere (the largest lake in England) that contains a visually and chemically distinct, $2 \mathrm{~cm}$ thick MTD. Evidence is provided that the MTD was triggered by an earthquake with a local magnitude of $4.7 \mathrm{ML}$ occurring on $26^{\text {th }}$ of December 1979 with an epicentre $70 \mathrm{~km}$ north of the lake. The earthquake was one of the largest in the UK during the last 100 years.

The role of earthquakes and climate in the formation of diamictic sediments was examined by Woodward et al (2018) in a New Zealand alpine lake. Different events with environmental significance are diamictic layers determined by facies classification based on XRF core-scanning in combination with magnetic susceptibility, grain size analysis and $\mu \mathrm{CT}$-scanning on a last 2000 years of a sediment record from Lake Chappa'ai in the Southern Alps of New Zealand. Although it was possible to distinguish diamictic sediment layers from increased iron (Fe) and decreased organic matter (inc/coh), their depositional processes were inferred to be linked to strong earthquakes. However, also ice-rafted debris, rockfalls as well as snowmelt or other runoff events were also considered as possible causes of the diamict layers.

Storm records: Frequency and intensity of storms was reconstructed for wind-exposed Loch Hosta, a lake located at the western shore of one of the Outer Hebridean Islands, U.K. (Orme et al., 2016). This study is based on $\mathrm{Ca} / \mathrm{K}$ as an indicator of calcium-rich marine beach sand being blown into the coastal lake. In combination with instrumental calibration, high resolution XRF data allow reconstruction of enhanced storminess during the climatic deterioration of the Little Ice Age (LIA). Additionally, the ca. 60-year cyclicity relates this palaeostorm record to the North Atlantic Oscillation (NAO) and North Atlantic sea-surface temperatures (Orme et al., 2016).

Another wind-related study tested long-term changes of tropical cyclone activity in the western North Atlantic region. At Robinson Lake, a lagoon at the Atlantic coast of Nova Scotia (Canada) and close to the north-western limit of tropical cyclone pathways, $\mathrm{Br} / \mathrm{Ti}$ indicates past cyclone activity (Oliva et al., 2018). As $\mathrm{Br}$ is a proxy for marine organic matter (Ziegler et al., 2008) 
and $\mathrm{Ti}$ is depleted in coarse-grained sediment fractions, $\mathrm{Br} / \mathrm{Ti}$ relates to high magnitude storms that transport coarse sediment rich in marine organic matter into Lake Robinson (Oliva et al., 2018). In this way, increased magnitude and frequency of tropical cyclones was detected for CE 1475-1670, i.e. for the early LIA.

Hydroclimatic studies: There are many hydroclimatic research studies across all climatic zones where elemental variability (e.g. $\mathrm{Ti}, \mathrm{Ti} / \mathrm{Ca}, \mathrm{Zr} / \mathrm{Ti}$ determined using XRF-CS) have been used as proxies for precipitation-driven sediment erosion (Hassall 2017, Schillereff et al., 2019; Chiverrell et al., 2019, Zolitschka et al., 2019). In particular, high resolution hydroclimatic records from tropical, continental Asia are relatively scarce and XRF core-scanning of the sediment record from Shuangchi Lake (Hainan Island, southern China) filled a gap in climate reconstructions (Zhang et al., 2018). Supported by grain size analyses, $\mathrm{Zr} / \mathrm{Rb}$ and $\mathrm{Si} / \mathrm{Ti}$ were interpreted as representing a higher median grain size, while $\mathrm{Rb} / \mathrm{Sr}$ and $\mathrm{Rb} / \mathrm{K}$ are related to finer grain sizes. Grain-size variability was in turn interpreted as a precipitation signal that documented higher rainfall during the LIA consistent with other East Asian palaeorecords. This evidence suggested a contraction of the Intertropical Convergence Zone and a strengthening of the Pacific Walker Circulation as the underlying climatic driver (Zhang et al., 2018).

Clastic events identified in the 7000 year-long lacustrine sediment record from Lac Pavin (Massif Central, France) indicated that increases in Ti were a reliable indicator of detrital minerogenic matter transferred from the catchment area into the lake. This erosional signal is linked to hydroclimatic fluctuations (i.e. an Atlantic precipitation signal) as human impact on this lacustrine system was insignificant until the Middle Ages (Chassiot et al., 2018). Rainfall variability seems to be controlled by negative phases of the NAO in concert with low total solar irradiance jointly triggering catchment soil erosion and mass-movements (Chassiot et al., 2018). Furthermore, Fe and Mn distinguish oxygenated Middle- to Late-Holocene bottom waters from anoxic conditions over the last ca 700 years. In the latter case, both elements co-vary with organically bound $\mathrm{Br}$, while $\mathrm{Fe}$ and $\mathrm{Mn}$ are distinctly linked to terrigenous detrital elements ( $\mathrm{Ti}, \mathrm{K}, \mathrm{Zr}, \mathrm{Rb}, \mathrm{Sr}, \mathrm{Ca}$ ) for the earlier section of the record (Chassiot et al., 2018). This trend from an oligotrophic lacustrine system with clastic sediment influx to a higher trophic level with organic sediments reflects the lake's ontogeny, a process promoted by cultural eutrophication during the last millennium.

The last 4500 year palaeolimnology of Lake Butrint, a coastal lagoon in southwestern Albania has been studied with a multiproxy approach that included XRF core-scanning (Morellón et al., 2016). $\mathrm{Ti} / \mathrm{Ca}$ was interpreted to characterise minerogenic sediment influx from the catchment area with Increasing $\mathrm{Ti} / \mathrm{Ca}$ supported by lower lake-water salinity (decrease in $\mathrm{Sr}$ ) due to more humid conditions with higher runoff during the LIA. However, if Ti/Ca and $\mathrm{Sr}$ rise contemporaneously, this points to cultural soil erosion without climatic forcing. Additionally, more saline, dry and warm 
periods with limited clastic input relate to Roman and Medieval Warm Periods. All changes are accompanied by variations of redox conditions as indicated by Fe/Mn (Morellón et al., 2016).

Information about the strength and position of Southern Hemispheric Westerlies has been obtained from the sediment record of Laguna Azul in southern Patagonia, Argentina (Zolitschka et al., 2019). An Early-Holocene rise of $\mathrm{Fe} / \mathrm{Mn}$ indicates strong meromixis with distinct anoxia at the lake bottom interpreted as the result of intensified westerly winds causing a drastic lake-level drop with salinization of the lake water. During the Late-Holocene, $\mathrm{Ca} / \mathrm{Ti}$ corresponds to minor lake-level fluctuations with addition of $\mathrm{Ca}$ to the sediment (calcite precipitation) during lower lake levels caused by windier, warmer and drier hydroclimatic conditions. In the absence of tributaries, Ti was linked at Laguna Azul to detrital minerogenic matter reflecting lake-shore erosion caused by fluctuating lake levels (Zolitschka et al., 2019).

XRF core-scanning also complements grain-size analysis but with much higher resolution. This approach was applied to a sediment record from the flooded sinkhole of Cenote Jennifer in northern Cuba (Peros et al., 2017). Higher concentrations of $\mathrm{Cl}$ and $\mathrm{Br}$ were used to detect increases in salinity caused by regional drying. Palaeoclimate reconstructions from Cenote Jennifer document a multistage 8.2 ka event (Peros et al., 2017) in agreement with greyscale data obtained from Cariaco Basin (Hughen et al., 1996).

Another Holocene sediment record with high resolution XRF core-scanning data comes from thermokarst Lake Herschel (Herschel Island, northern Yukon, Canada) that documented the life cycle of an Arctic freshwater ecosystem (Fritz et al., 2018). Variability of $\mathrm{Mn} / \mathrm{Fe}$ was related to changing redox conditions with consequences to the preservation of organic matter as indicated by inc/coh supported by discrete analyses of sediment total organic carbon. Additionally, $\mathrm{Rb} / \mathrm{Sr}$ as a grain-size proxy is interpreted as a signal of reduced precipitation and runoff from the catchment area and/or response to reduced weathering, a process sensitive to temperature variations. Finally, Sr/Ca was used as a salinity proxy that documented the development from a shallow saline to a deeper freshwater lake over the course of the Holocene (Fritz et al., 2018).

Holocene hydroclimatic variability was reconstructed using $\mathrm{Ca} / \mathrm{Fe}$ for Lake Strzeszyńskie in western Poland (Pleskot et al., 2018). Ca is diluted in the sediments during wetter and colder periods due to the formation of a deeper lake, while Fe increases, at the same time, are caused by redox processes induced by the development of more anoxic bottom water conditions. Accordingly, under drier and warmer climatic conditions the lake level drops. This causes higher concentrations of $\mathrm{Ca}$ and also of nutrients resulting in eutrophication with intensified calcite precipitation from the water column, while a shallower lake has oxygenated bottom waters and thus lower levels of Fe (Pleskot et al., 2018). These reconstructions correspond to other palaeorecords from Poland and to the lake- 
level reconstruction for Central Europe (Magny, 2004). As such, $\mathrm{Ca} / \mathrm{Fe}$ is a proxy for supraregional hydroclimatic variability for the site of Lake Strzeszyńskie (Pleskot et al., 2018).

The extraction of hydroclimatological records from lake sediments from the South Pacific Convergence Zone (SPCZ) is currently underway with a focus on reconstructing the movement of the SPCZ over millennial timescales (Hassall, 2017; Maloney et al 2019). In tropical lake systems where soil in-wash is mainly determined by rainfall amount, high resolution micro-XRF variability of insoluble soil-derived elements ( $\mathrm{Ti}$ in particular) present in the catchment soils are a proxy for changes in precipitation. This approach will ultimately allow reconstructions of precipitation records that will augment the existing short instrumental datasets.

\section{XRF core-scanning and varves}

In general, high resolution XRF core-scanning provides powerful proxy datasets with which to interpret processes affecting lake sediments. However, achievement of the full potential of this method is mostly hampered by age/depth models that rely on limited age control. Therefore, allying XRF core-scanning with annually laminated (varved) sediment records provides an ideally matched combination. While micro-XRF core scanning typically provides a spatial resolution of $0.2 \mathrm{~mm}$, the varves comes with a global mean annual resolution of $1.84 \mathrm{~mm} \mathrm{yr}^{-1}$ (Ojala et al., 2012). This allows XRF core-scanning to theoretical provide a mean resolution of nine data points per year, thereby opening a gateway to a new dimension of environmental reconstruction that will feed the growing demands of high resolution ecosystem and climate modelling.

The focus of this section involves maximising the output of XRF scanning-systems in combination with varved lake sediments. A gravity core with very finely laminated sediments was recovered from proglacial Lake Donguz-Orun (Central Caucasus, Russia) and was assumed to be varved (Alexandrin et al., 2018). As a typical proglacial varve consists of a coarse-grained summer and a fine-grained winter couplet, this distinct textural variation was checked by micro XRF corescanning data. Here $\mathrm{Zr} / \mathrm{Rb}$ was interpreted to record coarse-grained sediments, while $\mathrm{Rb} / \mathrm{Sr}$ corresponds to fine-grained sediments. Both alternate consistently in the record from Lake DonguzOrun. The counting of $\mathrm{Rb} / \mathrm{Sr}$ and $\mathrm{Zr} / \mathrm{Rb}$ maxima produced, within the respective error margins, the same number of couplets as years determined by radiometric dating $\left({ }^{137} \mathrm{Cs},{ }^{210} \mathrm{~Pb}\right.$ ) (Alexandrin et al., 2018). The terrigenous elements Fe and Ti were used for generation of a climate change signal with both elements correlating positively with instrumental records of annual precipitation (causing runoff) and summer temperature (causing glacier melt) from a nearby weather station (Alexandrin et al., 2018).

Another clastic depositional system is Chevalier Bay, a coastal embayment on Melville Island (Northwest Territories, High Arctic Canada). Its varved sediment record provides a well-constrained 
chronology back to CE 1670 (Amann et al., 2017). After carrying out a calibration study, the coarsegrained nival spring sub-laminae, best characterised by $\mathrm{Zr} / \mathrm{K}$, were regarded as a proxy for snowmeltrelated sediment transfer into Chevalier Bay. This calibration documents confinement of the signal to an extended winter season (November through March) and thus provides one of the few wellcalibrated records of winter temperature and snowfall conditions for the High Arctic (Amann et al., 2017).

Springtime snowmelt floods have also been archived in the varved sediment of Lake Kortejärvi (Eastern Finland). The 2700-year record studied using microfacies analysis and $\mu$ XRF scanning documents a significant correlation between detrital layer thickness and $\mathrm{Ti}$ as a terrigenous source indicator. Statistical links between detrital layer thickness and Ti to winter precipitation were established by calibration studies to produce a 2700 year-long annual scale reconstruction of snowfall (Czymzik et al., 2018).

The varved sediment record extracted from Etoliko Lagoon, on the lonian coast of Western Greece, spans the last 500 years (Koutsodendris et al., 2017). During the final stages of the LIA (since CE 1740), the sensitivity of sediments to record climatic changes was enhanced and is best documented by a three-fold increase in varve thickness, which goes along with environmental variability documented by $\mu \mathrm{XRF}$ data. Ti/Ca was driven by influx of minerogenic matter (Ti) versus autochthonous sediment by calcite precipitation (Ca). Increased Ti/Ca reflected increased catchment runoff and a resulting deeper lake, which was also reflected by stronger anoxia that drove higher $\mathrm{Fe} / \mathrm{Mn}$. At the same time, $\mathrm{Si} / \mathrm{Ti}$, a proxy for lacustrine (diatom) productivity, increased due to nutrient influx via catchment runoff. During a cold phase of the LIA from CE 1790-1830, Ti/Ca decreased indicating reduced runoff and enhanced calcite precipitation - with both linked to drier conditions (Koutsodendris et al., 2017). This in turn causes the lake level to drop with reduced anoxia (decreasing $\mathrm{Fe} / \mathrm{Mn}$ ) as well as higher salinity (increasing $\mathrm{Sr} / \mathrm{Ca}$ ) and higher concentration of nutrients (increasing Si/Ti). Consequently, the well dated high resolution $\mu \mathrm{XRF}$ data set in combination with precise dating from Etoliko Lagoon enabled Koutsodendris et al. (2017) to conclude that large-scale NAO shifts caused the observed climate variability during the LIA.

While the interpretation of XRF data for Etoliko Lagoon is descriptive, a multivariate statistical approach is applied to evaluate the entire XRF core-scanning data-set for the EarlyHolocene varved sediments from Meerfelder Maar, a crater lake in the West Eifel Volcanic Field in Germany (Martin-Puertas et al., 2017). This showed that multivariate statistics applied to high resolution XRF core-scanning data in combination with microfacies analyses (Figure 5) and the multiproxy approach allow an objective determination of depositional environments in terms of sediment sources and formation (Martin-Puertas et al., 2017). 
A multivariate statistical procedure was applied to the varved sediment record from Lake Montcortés (Central Pyrenees, Northern Spain) to determine shifts in oxic/anoxic conditions with the aim to distinguish climatic from human influences on the palaeolimnology since CE 1500 (VegasVilarrubia et al., 2018). Principal component and numerical clustering analyses allowed establishment of the evolution of oxic/anoxic conditions for the sediment record that resulted from manifold climatic and anthropogenic influences on the lacustrine ecosystem and catchment. Fortyfive percent of the sediment record indicated years with mixing conditions confirming the meromictic conditions are not required to preserve a continuously varved sediment record (cf., Zolitschka et al., 2015). The majority of varved sediment records the intensity of anoxia increased during the 20th century due to the effects of cultural eutrophication (Jenny et al., 2016). However, Lake Montcortés is different as it documents intensified anoxia in the second half of the 20th century despite ongoing and economically enforced regional depopulation since CE 1900, which caused oxygenation of the lake bottom only at the beginning of the 20th century. This points to global warming as the critical factor driving anoxia at Lake Montcortés (Vegas-Vilarrubia et al., 2018).

\section{XRF core scanners and other palaeoenvironmental records}

Dendrochemical studies: The application of XRF core scanners for high spatial resolution elemental analysis of annually-resolved tree-rings in wood sections is well established (e.g., Smith et al., 2014). Micro-XRF instruments provide a non-destructive tool for this emerging field and potentially allow tree responses to environmental conditions to be critically tested. Hevia et al. (2018) note from their research that high resolution records from old trees growing in remote, high elevation areas allow reconstruction of environmental changes. Century-scale chronologies of chemical variation at inter- and intra-annual resolution are few and a $\mu$ XRF study of elemental profiles in wood from Pyrenean high altitude pine forests growing on acidic and basic soils was evaluated. By studying changes in tree age and diameter relative to environmental influences (e.g., climate warming), elemental variations in sapwood (SW) and heartwood (HW) during the preindustrial (1700-1849) and industrial (1850-2008) periods were investigated. Tree-ring growth, wood density and relative element concentrations on annual and seasonal scales (early-wood, EW; late-wood, LW) were compared with climate variables (temperature and precipitation) and volcanic eruptions in the 18th and 19th centuries. Differences were identified for many elements between SW and HW along the stem and also between EW and LW within rings. Long-term positive and negative trends were observed for $\mathrm{Ca}$ and $\mathrm{K}$, respectively, while $\mathrm{Cl}, \mathrm{P}$ and $\mathrm{S}$ showed increasing trends over the industrial period. 
Mumiyo mounds: Hard waxy, laminated structures that form near the nests on ice-free rocky slopes of some sea birds are termed mumiyo mounds (Ainley et al 2006). These often represent longstanding accumulations of ejected stomach oil (a fishy, oily mixture used to feed young) are used by some sea birds to defend their nests from other marauding sea birds. In some cases, evidence is found that these ejecta form laminated accumulations that span millennia. A common producer of mumiyo mounds is the Snow Petrel (Pagodroma nivea), a common Southern Ocean sea bird, that feeds over pack-ice covered seas and nests on ice-free rocky slope on the Antarctic margin. The food available to these birds generally needs to be found within a day's flying and is dominated by either krill or fish which in turn depend on sea ice cover. The relative bias in diet impacts on the elemental chemistry of the mumiyo. Geochemical and ${ }^{14} \mathrm{C}$ dating studies of some deposits show that many generations of $P$. nivea must have re-occupied the same ice-free nesting sites for as long as 35,000 years (Thor and Low, 2011; Berg et al., 2018). Combining Itrax elemental studies with stable isotope and biomarker analyses of profiles through mumiyo mounds indicate food web and Antarctic climate fluctuations over the time-scale of their accumulation (Berg et al., 2018).

\section{Other applications}

Aside from sedimentological studies and related applications (Figure 1 to 5, Table 1), high resolution XRF scanning technology has been applied in other fields such as forensic geochemistry, environmental remediation and protection as well as mineral exploration.

Forensic geochemistry: Geochemical data used to support legal investigations of illegal environmental pollution fall into the realm of environmental or geochemical forensics. An example of such an investigation involving sediment core scanning is the Augusta Harbour (Sicily) study. This highly polluted harbour was the subject of a legal investigation to establish whether companies responsible for causing significant heavy metal pollution (particularly $\mathrm{Hg}, \mathrm{Cu}, \mathrm{Ba}$ etc) could be identified and made accountable for the cost of environmental remediation. High resolution XRF core scanning data and radionuclide dating contributed key scientific evidence to assist in the legal process (Croudace et al, 2015).

Environmental remediation: Remediation of contaminated soil (e.g. radionuclides, heavy metals) either in-situ or in engineered tanks is an important practice. One method investigated used a low voltage electrokinetic process to drive electrolytic reactions in soil contaminated by $\mathrm{U}$ and $\mathrm{Pu}$ from a nuclear weapons site in the southern UK (Agnew et al 2014). Pilot-scale experimental tanks filled with the contaminated soil were subjected to the electrokinetic process for two weeks. The tanks were then scanned using an XRF core scanner to evaluate the extent of migration and distribution of elements through the treated soil. The experiment allowed a mechanistic 
understanding of element mobility and rates of migration to be developed. The leaching and accumulation processes of heavy metals in soils require both temporal and spatial variations in metal concentrations in the test cells to be assessed.

Environmental protection: The rapid and non-destructive capabilities of XRF core scanners allows the efficient monitoring of reactors holding contaminated soil. During experimental runs, designed to simulate natural and anthropogenic conditions, leaching using various agents was applied. The purpose was to infer how key pollutant elements $(\mathrm{Ni}, \mathrm{Cd}, \mathrm{Pb})$ elements might behave in nature as a response to acidic precipitation or the release of acidic waste waters. The transport and subsequent re-deposition of pollutant elements were studied over time. The study was performed by the Department of Bioenvironmental Systems Engineering at the National Taiwan University.

Another recently developed method (Huang et al. 2019) uses the efficiency of XRF core scanners to measure multiple, sequentially deployed sachets of ion exchange resins to assess environmental pollution of natural waters. The procedure has the potential to become a standard method for large scale monitoring and detection of heavy metal pollution in non-marine aqueous systems. The ion exchange resin sachets are placed in the waters for a certain period of time, then retrieved and placed in sample holders, and then run through an XRF core scanner. The amount of heavy metals taken up by the resin is directly proportional to the concentration in the water. The XRF core-scanner results can be used to identify and quantify sources and distribution of heavy metal pollution in, for example, river networks and irrigation channel systems. Other potential applications include long term monitoring of water quality of aquacultures, industrial waste water drainage systems, as well as natural river catchments. The low cost and easy handling of the resin samples makes them suitable for large-scale citizen science projects such as engaging local schools to participate in the monitoring of local surface water quality.

Mineral exploration: XRF core scanning is now established as an efficient non-destructive tool in the international mining industry to rapidly extract elemental information from rock core sections and to inform metalliferous exploration strategies (Sjöqvist et al., 2015). The recently developed Minalyze Core Scanner combines rapid XRF core scanning with advanced topographic mapping and high resolution imagery to enable three-dimensional visualization of core features such as faults, veins, and geological structures superimposed on geochemical data obtained from XRF scanning. As matrix effects in lithified core material typically are smaller than for unlithified, wet marine and lacustrine sediments, it is sufficient for a small number of reference materials to be employed to convert data from semi-quantitative to quantitative.

\section{Conclusions}


XRF sediment core scanners have become crucial analytical tools in the environmental geosciences providing proxy indicators of past environmental change. Increasingly these scanners are now being applied in other scientific areas. Their key attributes are the ability to automatically acquire high resolution elemental profiles rapidly and non-destructively. Most high resolution XRF core scanners have been designed to scan along the length of metre long cores (1D) but smaller $x-y-z$ (2D) systems that allow elemental mapping at high spatial resolution have become important complementary systems.

High resolution XRF core scanners offer many opportunities for generating large amounts of data and users need to beware the temptation of over-interpreting their data. A proper appreciation of the variabilities and controls on elemental excitation efficiencies by $X$-rays, the impact of tube ageing, sample matrix, grain size and low $Z$ elements on sensitivity as well as an understanding of the typical geochemical abundances of elements in the system studied are essential pre-requisites for instrument users. In most cases, users should aim to use calibrated instrumental data to validate elemental profiles or ratios based on initial count-rate data. Applying such calibrations should be seen as crucial to provide robust sediment records. The importance of visualising closed-sum data using ratios and log ratios should also be understood by users. Well established elemental indicators are widely used by the community (e.g. Ti variations as a proxy for terrigenous minerogenic matter) and a few XRF-derived ratios (inc/coh as a proxy for organic matter; Fe/Mn as a proxy for redox conditions; $\mathrm{Rb} / \mathrm{Sr}$ as a grain-size proxy) but a critical appraisal and justification on a case by case basis is always necessary.

Investigators using $\mu$-XRF core scanners require an in-depth knowledge of the systems under evaluation. For example, in a lacustrine system knowledge of the catchments geology, hydrological conditions, land use patterns and the overall climatic realities are required to properly interpret elemental profile data. Good time control is invariably required in many studies and can be inferred from microtextural and geochemical properties in some cases or from radiometric and other means. Long environmental reconstructions with annual resolution also make proper use of the technical capabilities of XRF core-scanning.

\section{Acknowledgements}

As Guest Editors for the Special Issue on XRF Core Scanners we are grateful to the National Taiwan University and its academic staff who generously and enthusiastically hosted and organised the International XRF Core Scanning 2017 Conference and Field Excursion held in Taipei (March 2017). Particular thanks go to Jyh-Jaan Steven Huang for his role in the organisation. The meeting stimulated many of the contributions found in the QI Special Issue. We also appreciate the support and/or technical data supplied by the instrument manufacturers. Finally, we thank the two anonymous reviewers who helped improve the manuscript.

\section{References}


Agnew K., Cundy A.B., Hopkinson L., Croudace I.W., Warwick P.E., Purdie P., 2011. Low-energy electrokinetic remediation of plutonium-contaminated nuclear site soil wastes: results from a pilot-scale on-site trial. J. Hazard. Mater., 186, 1405-1414.

Ainley D. G., Hobson K. A., Crosta X., Rau G. H., Wassenaar L. I., Augustinus P. C., 2006. Holocene variation in the Antarctic coastal food web: Linking $\delta D$ and $\delta 13 C$ in snow petrel diet and marine sediments. Marine Ecology Progress Series 306, 31-40.

Aitchison, J., 1982. The statistical analysis of compositional data. J. Royal Stat. Soc. Series B (Methodological) 44, 139-177.

Aitchison, J., Greenacre, M., 2002. Bi-plots of compositional data. J. Royal Stat. Soc. Series C (Applied Statistics) 51, 375-392.

Alexandrin, M.Y., Darin, A.V., Kalugin, I.A., Dolgova, E.A., Grachev, A.M., Solomina, O.N., 2018. Annual sedimentary record from Lake Donguz-Orun (Central Caucasus) constrained by high resolution SR-XRF analysis and its potential for climate reconstructions. Frontiers Sci., 6.

Amann, B., Lamoureux, S.F., Boreux, M.P., 2017. Winter temperature conditions (1670-2010) reconstructed from varved sediments, western Canadian High Arctic. Quat. Sci. Rev., 172, 1-14.

Berg S., Melles M., Hermichen W.D. McClymont E.L., Bentley M.J., Hodgson D.A., Kuhn G., 2019. Evaluation of mumiyo deposits from East Antarctica as archives for the Late Quaternary environmental and climatic history. Geochem. Geophys. Geosyst., 20, 260-276.

Bloemsma, M.R., Zabel, M., Stuut, J.B.W., Tjallingii, R., Collins, J.A., Weltje, G.J., 2012. Modelling the joint variability of grain size and chemical composition in sediments. J. Sediment. Geol., 280, 135-148.

Bloemsma, M.R., 2015. Development of a Modelling Framework for Core Data Integration using XRF Scanning 217. PhD Thesis, TU Delft, //doi.org/10.4233/uuid:95a90787-edc7-4f1f-9e6a-b2453effabdb.

Boyle, J.F., Chiverrell, R.C. and Schillereff, D., 2015. Lake sediment chemical stratigraphies measured by Delta XRF a nalyser on a Geotek Multisensor Core Logging system. in Croudace I.W. \& Rothwell R.G. (eds) Micro-XRF Studies of Sediment Cores (Springer Series-Developments in Palaeoenvironmental Research).

Chassiot, L., Miras, Y., Chapron, E., Develle, A.-L., Arnaud, F., Motelica-Heino, M., Di Giovanni, C., 2018. A 7000year environmental history and soil erosion record inferred from the deep sediments of Lake Pavin (Massif Central, France). Palaeogeog., Palaeoclimat. Palaeoecol., 497, 218-233.

Chiverrell, R.C., Sear, D.A. Warburton, J, Macdonald, N., Schillereff, D.N., Dearing, J.A., Croudace, I. W., Brown, J., Bradley, J. 2019, Using lake sediment archives to improve understanding of flood magnitude and frequency: recent extreme flooding in northwest UK. ESPL (in proof)

Croudace, I.W., Rindby, A., Rothwell, R.G., 2006. ITRAX: description and evaluation of a new multi-function Xray core scanner. Geol. Soc., Lond., Spec. Publ., 267, 51-63.

Croudace I.W. Warwick P.E., Morris J.E., 2012. Evidence for the preservation of technogenic tritiated organic compounds in an estuarine sedimentary environment. Environ. Sci. Technol., 46, 5704-5712.

Croudace I.W., Romano, E., Rothwell, R.G., Bergamin, L., 2015. Application of micro-XRF core scanners to environmental forensic investigations: a case study of polluted harbour sediment from Augusta Bay, Sicily in Croudace I.W. \& Rothwell R.G. (eds) Micro-XRF Studies of Sediment Cores (Springer Series-Developments in Palaeoenvironmental Research.

Croudace I.W., Teasdale P.A., Cundy A.B., 2019. 200-year industrial archaeological record preserved in an Isle of Man saltmarsh sediment sequence: Itrax and radiochronological evidence. Quat. Int xxxxxxx

Croudace I.W., Löwemark, L., Tjallingii, R., Zolitschka, B., 2019. Current perspectives on the capabilities of high resolution XRF core scanners. Quat. Int.

Czymzik, M., Haltia, E., Saarni, S., Saarinen, T., Brauer, A., 2018. Differential North Atlantic control of winter hydroclimate in late Holocene varved sediments of Lake Kortejärvi, eastern Finland. Boreas 47, 926-937.

Davies, S.J., Lamb, H.F., Roberts, S.J., 2015. Micro-XRF Core scanning in palaeolimnology: recent developments, in: Croudace, I.W., Rothwell, R.G. (Eds.), DPER. Springer, Dordrecht, pp. 189-226.

Dulski, P., Brauer, A., Mangili, C., 2015. Combined $\mu$-XRF and microfacies techniques for lake sediment analyses. In: I. W. Croudace, Rothwell, R.G. (Eds.), Micro-XRF Studies of Sediment Cores. Springer Science and Business Media Dordrecht, pp. 325-349. 
Ellis, B., Grant, K., Mallela, J., Abram, N., 2019. Is XRF core scanning a viable method for coral palaeoclimate temperature reconstructions? Quat. Int. xxxxxxx

Fielding J.J., Kemp A.E.S., Bull J.M., Cotterill C.J., Pearce R.B., Avery R.S., Langdon P.G., Croudace I.W., 2018. Palaeoseismology from microfabric and geochemical analysis of lacustrine sediments, Windermere, UK. J. Geol. Soc., 175, 903-914.

Fielding J.J., Croudace I.W., Kemp A.E.S., Pearce R.B., Bull J.M., Cotterill C.J., Langdon P.G., Avery R. (2019) A 200 year history of lake pollution, eutrophication and partial recovery from Windermere, UK, reconstructed from geochemistry and sediment fabric analysis. Sci. Tot. Env.

Fritz, M., Unkel, I., Lenz, J., Gajewski, K., Frenzel, P., Paquette, N., Lantuit, H., Körte, L., Wetterich, S., 2018. Regional environmental change versus local signal preservation in Holocene thermokarst lake sediments: $A$ case study from Herschel Island, Yukon (Canada). J. Paleolimn., 60, 77-96.

Gracia, E., Lamarche, G., Nelson, H., Pantosti, D., 2013. Preface: Marine and Lake Paleoseismology. Nat. Hazard Earth Sys., 13, 3469-3478.

Gregory, B.R.B., Patterson, R.T., Reinhardt, E.G., Galloway, J.M., 2019. The iBox-FC: A new containment vessel for Itrax X-ray fluorescence core scanning of freeze cores. Quat. Int. xxxxxxx

Haschke, M., 2006. The Eagle III BKA system, a novel sediment core X-ray fluorescence analyser with very high spatial resolution. In: Rothwell, R.G. (Ed.), New Techniques in Sediment Core Analysis. Geol. Soc. Lond., Spec Pub. 267, pp. 31-37.

Hassall, J.D., 2017. Static or Dynamic: Reconstructing past movement of the South Pacific Convergence Zone, PhD Thesis, Uni. Southampton, https://eprints.soton.ac.uk/id/eprint/415345.

Haug, G., Hughen, K., Sigman, D., Peterson, L., Röhl, U., 2001. Southward migration of the Intertropical Convergence Zone through the Holocene. Science, 293, 1304-1308.

Haug, G., Gunther, D., Peterson, L., Sigman, D., Hughen, K., Aeschlimann, B., 2003. Climate and the collapse of Maya civilization. Science 299, 1731-1735.

Hennekam, R., Sweere, T., Tjallingii, R., de Lange, G.J., Reichart G-J., 2019. Trace metal analysis of sediment cores using a novel X-ray fluorescence core scanning method, Quat. Int.

Hevia A, Sánchez-Salguero R., Camarero J.J., Buras A., Sangüesa-Barreda G., Galván J.D., Gutiérrez E., 2018. Towards a better understanding of long-term wood-chemistry variations in old-growth forests: A case study on ancient Pinus uncinata trees from the Pyrenees. Science of the Total Environment 625, 220-232.

Huang, J.-J. S., Wei, K.-Y., Löwemark, L., Song, S.-R., Chuang, C.-K., Yang, T.-N., Lee, M.-Y., Chen, Y.-B., Horng, C.S., Chen, K.-H, Lee, T.-Q., 2019. What caused the cultural hiatus in the Iron-Age Kiwulan Site, northeastern Taiwan? Quat. Int., xxxxxxx

Huang, J.-J. S, Lin S.-C., Löwemark, L. Liou, Y.-H., Chang, Q., Chang, T. -K., Wei, K.-Y., Croudace, I.W. (2019) Rapid assessment of heavy metal pollution-monitoring using ion-exchange resin sachets and micro-XRF core-scanning. Sci. Rep., xxxxxxxx

Hughen, K.A., Overpeck, J.T., Peterson, L.C., Anderson, R.F., 1996. The nature of varved sedimentation in Cariaco Basin, Venezuela, and its paleoclimatic significance, in: Kemp, A.E.S. (Ed.), Paleoclimatology and Paleooceanography From Laminated Sediments, London, pp. 171-183.

Itrax operators, Bloemsma, M., Croudace, I.W., Daly, J.S., Edwards, R.J., Francus, P., Galloway, J.M., Gregory, B.R.B., Huang, J.-J.S., Jones, A.F., Kylander, M., Löwemark, L., Luon, Y., Maclachlan, S., Ohlendorf, C., Patterson, R.T., Pearce, C., Profe, J., Reinhardt, E.G., Stranne, C., Tjallingii, R., Turner, J.N., 2019. Practical guidelines and recent advances in the Itrax XRF core-scanning procedure, Quat. Int.

Jansen, J.H.F., Van der Gaast, S.J., Koster, B., Vaars, A.J., 1998. CORTEX, a shipboard XRF-scanner for element analyses in split sediment cores. Mar. Geol., 151, 143-153

Jenny, J.P., Francus, P., Normandeau, A., Lapointe, F., Perga, M.E., Ojala, A., Schimmelmann, A., Zolitschka, B., 2016. Global spread of hypoxia in freshwater ecosystems during the last three centuries is caused by rising local human pressure. Glob. Change Biol., 22, 1481-1489.

Jones, A.F., Turner J.N. Daly, J. S., Francus, P., Edwards, R.J., 2019. Signal-to-noise ratios, instrument parameters and repeatability of Itrax XRF core scan measurements of floodplain sediments, Quat. Int.

Kaboth-Bahr, S., Denis, V., Su, C-C., O'Regan, M., Gyllencreutz, R., Jakobsson, M., Löwemark, L., 2019. Deciphering $\sim 45.000$ years of Arctic Ocean lithostratigraphic variability through multivariate statistical analysis, Quat. Int. xxxxxx 
Koutsodendris, A., Brauer, A., Reed, J.M., Plessen, B., Friedrich, O., Hennrich, B., Zacharias, I., Pross, J., 2017. Climate variability in SE Europe since $1450 \mathrm{AD}$ based on a varved sediment record from Etoliko Lagoon (Western Greece). Quat. Sci Rev., 159, 63-76.

Lengger, S.K., Kraaij, M., Tjallingii, R., Baas, M., Stuut, J.B., Hopmans, E.C., Sinninghe Damsté, J.S., Schouten, S., 2013. Differential degradation of intact polar and core glycerol dialkyl glycerol tetraether lipids upon postdepositional oxidation. Organ. Geochem., 65, 83-93.

Longman, J., Veres, D., Wennrich, V., 2019. Utilisation of XRF core scanning on peat and other highly organic sediments, Quat. Int. xxxxxxxx

Löwemark, L., Chen, H.F., Yang, T.N., Kylander, M., Yu, E.F., Hsu, Y.W., Lee, T.Q., Song, S.R., Jarvis, S., 2011. Normalizing XRF-scanner data: A cautionary note on the interpretation of high resolution records from organic-rich lakes. J. Asian Earth Sci., 40, 1250-1256.

López Pérez, A.E., Rey, D., Martins, V., Plaza-Morlote, M., Rubio, B., 2019. Application of multivariate statistical analyses to Itrax core scanner data for the identification of deep-marine sedimentary facies: A case study in the Galician Continental Margin, Quat. Int.

Magny, M., 2004. Holocene climate variability as reflected by mid-European lake-level fluctuations and its probable impact on prehistoric human settlements. Quat. Int., 113, 65-79.

Maloney A. E., Nelson D. B, Richey Julie N., Prebble Matthew, Sear D. A., Hassall J. D., Langdon P. G., Croudace I.W., Zawadzki A., Sachs J.P., 2019. Reconstructing precipitation in the tropical South Pacific from dinosterol $2 \mathrm{H} / 1 \mathrm{H}$ ratios in lake sediment. Geochim. Cosmochim. Acta 245, 190-206.

Martin-Puertas, C., Tjallingii, R., Bloemsma, M., Brauer, A., 2017. Varved sediment responses to early Holocene climate and environmental changes in Lake Meerfelder Maar (Germany) obtained from multivariate analyses of micro X-ray fluorescence core scanning data. J. Quat. Sci., 32, 427-436.

Miller, H., Croudace, I.W., Bull, J.M., Cotterill, C.J., Dix, J.K. and Taylor, R.N., 2014. A 500 year sediment lake record of anthropogenic and natural inputs to Windermere (English Lake District) using double-spike lead isotopes, radiochronology, and sediment microanalysis. Environ. Sci. Technol. 48, 7254-7263

Morellón, M., Anselmetti, F.S., Ariztegui, D., Brushulli, B., Sinopoli, G., Wagner, B., Sadori, L., Gilli, A., Pambuku, A., 2016. Human-climate interactions in the central Mediterranean region during the last millennia: The laminated record of Lake Butrint (Albania). Quat. Sci. Rev. 136, 134-152.

Ojala, A.E.K., Francus, P., Zolitschka, B., Besonen, M., Lamoureux, S.F., 2012. Characteristics of sedimentary varve chronologies - A review. Quat. Sci. Rev. 43, 45-60.

Oliva, F., Viau, A.E., Peros, M.C., Bouchard, M., 2018. Paleotempestology database for the western North Atlantic basin. The Holocene 28, 1664-1671.

Ön, Z.B. and Özeren, M.S., 2019. Temperature and precipitation variability in eastern Anatolia: Results from independent component analysis of Lake Van sediment data spanning the last $250 \mathrm{kyr} B P$, Quat. Int. xxxxxxxx

Orme, L.C., Reinhardt, L., Jones, R.T., Charman, D.J., Croudace, I.W., Dawson, A., Ellis, M., Barkwith, A., 2016. Investigating the maximum resolution of $\mu \mathrm{XRF}$ core scanners: An 1800 year storminess reconstruction from the Outer Hebrides, Scotland, UK. The Holocene, 26, 235-247.

Pennington, B.T., Hamdan, M.A., Pears, B.R., Sameh, H.I., 2019. Aridification of the Egyptian Sahara 5000-4000 cal BP revealed from X-ray fluorescence analysis of Nile Delta sediments at Kom al-Ahmer/Kom Wasit, Quat. Int. $x x x x x x x x$

Peros, M., Collins, S., G'Meiner, A.A., Reinhardt, E., Pupo, F.M., 2017. Multistage 8.2 kyr event revealed through high resolution XRF core scanning of Cuban sinkhole sediments. Geophys. Res. Lett., 44, 7374-7381.

Peterson, L.C., Haug, G.H., Hughen, K.A., Rohl, U., 2000. Rapid changes in the hydrologic cycle of the tropical Atlantic during the last glacial. Science, 290, 1947-1951.

Peti L., Augustinus P., Gadd P., Davies S., 2019. Towards fingerprinting rhyolitic tephra layers with rapid, nondestructive $\mu$-XRF core scanning. Quat. Int. xxxxxxx

Pleskot, K., Tjallingii, R., Makohonienko, M., Nowaczyk, N., Szczuciński, W., 2018. Holocene paleohydrological reconstruction of Lake Strzeszyńskie (western Poland) and its implications for the central European climatic transition zone. J. Paleolimnol., 59, 443-459.

Profe, J., Wacha, L., Frechen, M, Ohlendorf, C., Zolitschka, B., 2019. XRF scanning of discrete samples - A chemostratigraphic approach exemplified for loess-paleosol sequences from the Island of Susak, Croatia. Quat. Int. xxxxxxxx 
Profe, J., Ohlendorf, C. (2019) X-ray fluorescence scanning of discrete samples - An economical perspective, Quat. Int. xxxxxxx

Ramisch, A., Tjallingii, R., Hartmann, K., Diekmann, B., Brauer, A., 2018. Echo of the Younger Dryas in Holocene lake sediments on the Tibetan Plateau. Geophys. Res. Lett., 45, 11,154-11,163.

Richter, T.O., van der Gaast, S., Koster, B., Vaars, A., Gieles, R., de Stigter, H.C., de Haas, H. and van Weering, T.C.E. (2006) The Avaatech XRF Core Scanner: technical description and applications to NE Atlantic sediments. Geol. Soc. Lond., Spec. Publ.., 267, 39-50

Röhl, U., Abrams, L.J., 2000. From Sites 999 And 1001 In The Caribbean Sea: Application To The Late Paleocene Thermal Maximum. In: Leckie, R.M., Sigurdsson, H., Acton, G.F., Draper, G. (Eds.), Proc. Ocean Drilling Prog., Sci. Res. 165. pp. 191-203.

Rothwell, R.G., Croudace, I.W., 2015. Twenty years of XRF core scanning marine sediments: what do geochemical proxies tell us? in: Croudace I.W. \& Rothwell R.G. (eds) Micro-XRF Studies of Sediment Cores (Springer Series-Developments in Palaeoenvironmental Research, August 2015, pp. 25-102.

Rothwell, R.G., Hoogakker, B., Thomson, J., Croudace, I.W., Frenz, M., 2006. Turbidite emplacement on the southern Balearic Abyssal Plain (western Mediterranean Sea) during Marine Isotope Stages 1-3: an application of ITRAX XRF scanning of sediment cores to lithostratigraphic analysis. Geol. Soc. Lond., Spec. Publ., 267, 79-98,

Sakamoto, T., Kuroki, K., Sugawara, T., Aoike, K., lijima, K., Sugisaki, S., 2006. Non-destructive X-ray fluorescence (XRF) core-imaging scanner, TATSCAN-F2, Scientific Drilling, No. 2, 37-39.

Sánchez-Salguero R, Camarero JJ, Hevia A., Sangüesa-Barreda G, Galván J.D., Gutiérrez E., 2019. Testing annual tree-ring chemistry by X-ray fluorescence for dendroclimatic studies in high elevation forests from the Spanish Pyrenees. Quat. Int. xxxxxxxx

Schillereff, D.N., Chiverrell, R.C., Croudace, I.W. and Boyle, J., 2015. Lacustrine applications of $\mu$ XRF scanning: an inter-comparison of analytical methods in Croudace I.W. \& Rothwell R.G. (eds) Micro-XRF studies of Sediment Cores (Springer Series-Developments in Palaeoenvironmental Research, August 2015)

Schillereff, D.N., Chiverrell, R.C., Macdonald, N., Hooke, J.M., Welsh, K.E., Piliposian, G., Croudace, I.W. (2019) Convergent human and climate forcing of late-Holocene flooding in northwest England. Glob. Planet. Change

Schimmelmann, A., Lange, C.B., Schieber, J., Francus, P., Ojala, A.E.K., Zolitschka, B., 2016. Varves in marine sediments: A review. Earth-Sci. Rev., 159, 215-246.

Sjöqvist, A.S.L., Arthursson, M., Lundström, A., Estrada, E.C., Inerfeldt, A., Lorenz, H., 2015. An innovative optical and chemical drill core scanner. Scientific Drilling 19, 13-16.

Strasser, M., Monecke, K., Schnellmann, M., Anselmetti, F.S., 2013. Lake sediments as natural seismographs: A compiled record of Late Quaternary earthquakes in Central Switzerland and its implication for Alpine deformation. Sedimentology 60, 319-341.

Swindles G.T., Galloway J.M., Macumber A.L., Croudace I.W., Emery A.R., Woulds C., Bateman M.D., Parry L., Jones J.M., Selby K., Rushby G.T., Baird A.J., Woodroffe S.A., Barlow N.L.M., 2018. Sedimentary records of coastal storm surges: Evidence of the 1953 North Sea event. Mar. Geol., 403, 262-270.

Thomson, J., Croudace, I.W. and Rothwell, R.G., 2006. A geochemical application of the ITRAX scanner to a sediment core containing eastern Mediterranean sapropel units. Geol. Soc., Lond., Spec. Publ., 267, 65-77.

Thor G. and Low M., 2011. The persistence of the snow petrel (Pagodroma nivea) in Dronning Maud Land (Antarctica) for over 37,000 years. Polar Biol., 34,609-613.

Tjallingii, R., Röhl, U., Kölling, M., Bickert, T., 2007. Influence of the water content on X-ray fluorescence core scanning measurements in soft marine sediments. Geochem. Geophys. Geosys., 8, 1-12.

Tsobanoglou K., Croudace I.W., Birch H. and Collins M.B., 2010. Geochemical and radiochronological evidence of North Sea storm surges in salt marsh cores from The Wash embayment (UK). The Holocene, 21, 225-236.

Vegas-Vilarrubia, T., Corella, J.P., Perez-Zanon, N., Buchaca, T., Trapote, M.C., Lopez, P., Sigro, J., Rull, V., 2018. Historical shifts in oxygenation regime as recorded in the laminated sediments of lake Montcortes (Central Pyrenees) support hypoxia as a continental-scale phenomenon. Sci. Tot. Environ. 612, 1577-1592.

Wang, H., Li, H. Si, J., Zhang, L., Sun, Z., 2019. Geochemical features of the pseudotachylytes in the Longmen Shan thrust belt, eastern Tibet, Quat. Int. xxxxxxx

Weltje, G.J., Tjallingii, R., 2008. Calibration of XRF core scanners for quantitative geochemical logging of sediment cores: theory and application. Earth Planet. Sci. Lett., 274, 423-438. 
Weltje, G.J., Bloemsma, M.R., Tjallingii, R., Heslop, D., Röhl, U., Croudace, I.W., 2015. Prediction of Geochemical Composition from XRF Core Scanner Data: A New Multivariate Approach Including Automatic Selection of Calibration Samples and Quantification of Uncertainties. In: Croudace, I.W., Rothwell, R.G. (Eds.), Developments in Paleoenvironmental Research, Springer Science Dordrecht, pp. 507-534.

Woodward, C.A., Slee, A., Gadd, P., Zawadzki, A., Hamze, H., Parmar, A., Zahra, D., 2018. The role of earthquakes and climate in the formation of diamictic sediments in a New Zealand mountain lake. Quat. Int. 470, 130-147.

Woodward, C.A., Gadd, P.S., 2019. The potential power and pitfalls of using the X-ray fluorescence molybdenum incoherent: coherent scattering ratio as a proxy for sediment organic content. Quat. Int. $\operatorname{xxxxxx}$

Zhang, W.C., Yan, H., Liu, C.C., Cheng, P., Li, J.Y., Lu, F.Y., Ma, X.L., Dodson, J., Heijnis, H., Zhou, W.J., An, Z.S., 2018. Hydrological changes in Shuangchi Lake, Hainan Island, tropical China, during the Little Ice Age. Quat, Int., 487, 54-60.

Ziegler, M., Jilbert, T., de Lange, G.J., Lourens, L.J., Reichart, G.J., 2008. Bromine counts from XRF scanning as an estimate of the marine organic carbon content of sediment cores. Geochem. Geophys. Geosyst. 9, Q05009.

Zolitschka, B., Mingram, J., Van der Gaast, S., Jansen, J.H.F., Naumann, R., 2001. Sediment Logging Techniques, in: Last, W.M., Smol, J.P. (Eds.), Tracking Environmental Change Using Lake Sediments. Volume 1: Basin Analysis, Coring, and Chronological Techniques. Kluwer Academic Press, Dordrecht, pp. 137-153.

Zolitschka, B., Francus, P., Ojala, A.E.K., Schimmelmann, A., 2015. Varves in lake sediments - a review. Quat. Sci. Rev., 117, 1-41.

Zolitschka, B., Fey, M., Janssen, S., Maidana, N.I., Mayr, C., Wulf, S., Haberzettl, T., Corbella, H., Lücke, A., Ohlendorf, C., Schäbitz, F., 2019. Southern Hemispheric Westerlies control sedimentary processes of Laguna Azul (south-eastern Patagonia, Argentina). The Holocene, 29, 403-420. 
Table 1: Topics included in the QI:XRF Core scanner Special Issue

\begin{tabular}{|c|c|c|}
\hline Overview & Current perspectives on the capabilities of high resolution XRF core scanners. & Croudace et al, 2019 \\
\hline Methodology & Practical guidelines and recent advances in the Itrax XRF core-scanning procedure & Itrax specialists, 2019 \\
\hline Methodology & $\begin{array}{l}\text { The potential power and pitfalls of using the X-ray fluorescence molybdenum incoherent: coherent scattering ratio as a proxy for sediment organic } \\
\text { content }\end{array}$ & Woodward and Gadd, 2019 \\
\hline Methodology & Signal-to-noise ratios, instrument parameters and repeatability of Itrax XRF core scan measurements of floodplain sediments & $\underline{\text { Jones et al } 2019}$ \\
\hline Methodology & Trace metal analysis of sediment cores using a novel X-ray fluorescence core scanning method & Hennekam et al 2019 \\
\hline Methodology & X-ray fluorescence scanning of discrete samples: an economical perspective & Profe and Ohlendorf, 2019 \\
\hline Methodology & The iBox-FC: A new containment vessel for Itrax X-ray fluorescence core-scanning of freeze cores & $\underline{\text { Gregory et al, } 2019}$ \\
\hline Methodology & Utilisation of XRF core scanning on peat and other highly organic sediments & $\underline{\text { Longman et al, } 2019}$ \\
\hline
\end{tabular}

\begin{tabular}{|c|c|c|}
\hline Palaeoclimate & Is XRF core scanning a viable method for coral palaeoclimate temperature reconstructions? & Ellis et al, 2019 \\
\hline Palaeoclimate & Aridification of the Egyptian Sahara 5000-4000 cal BP revealed from X-ray fluorescence analysis of Nile Delta sediments at Kom al-Ahmer/Kom Wasit & Pennington et al, 2019 \\
\hline Palaeoclimate & $\begin{array}{l}\text { Temperature and precipitation variability in eastern Anatolia: results from independent component analysis of Lake Van sediment data spanning the last } \\
250 \mathrm{kyr}\end{array}$ & Ön and Özeren $\underline{2019}$ \\
\hline Palaeoclimate & Testing annual tree-ring chemistry by X-ray fluorescence for dendroclimatic studies in high elevation forests from the Spanish Pyrenees & Sanchez-Salguero et al, 2019 \\
\hline
\end{tabular}

\begin{tabular}{|c|c|c|}
\hline Sedimentology & Deciphering $\sim 45000$ years of Arctic Ocean lithostratigraphic variability through multivariate statistical analysis & $\underline{\text { Kaboth-Bahr et al, } 2019}$ \\
\hline Sedimentology & $\begin{array}{l}\text { Application of multivariate statistical analyses to Itrax core scanner data for the identification of deep-marine sedimentary facies: A case study in the } \\
\text { Galician Continental Margin }\end{array}$ & Lopez-Perez et al, 2019 \\
\hline
\end{tabular}

\begin{tabular}{|c|c|c|}
\hline Volcanology & Towards characterising rhyolitic tephra layers from New Zealand with rapid, non-destructive micro-XRF core scanning & Peti et al, 2019 \\
\hline Seismic Processes & Geochemical features of the pseudotachylytes in the Longmen Shan thrust belt, eastern Tibet & Wang et al, 2019 \\
\hline
\end{tabular}

\begin{tabular}{|c|c|c|}
\hline Geoarchaeology & 200-year industrial archaeological record preserved in an Isle of Man saltmarsh sediment sequence: Geochemical and radiochronological evidence & Croudace et al, 2019 \\
\hline Geoarchaeology & What caused the cultural hiatus in the Iron-Age Kiwulan Site, northeastern Taiwan? & Huang et al, 2019 \\
\hline
\end{tabular}




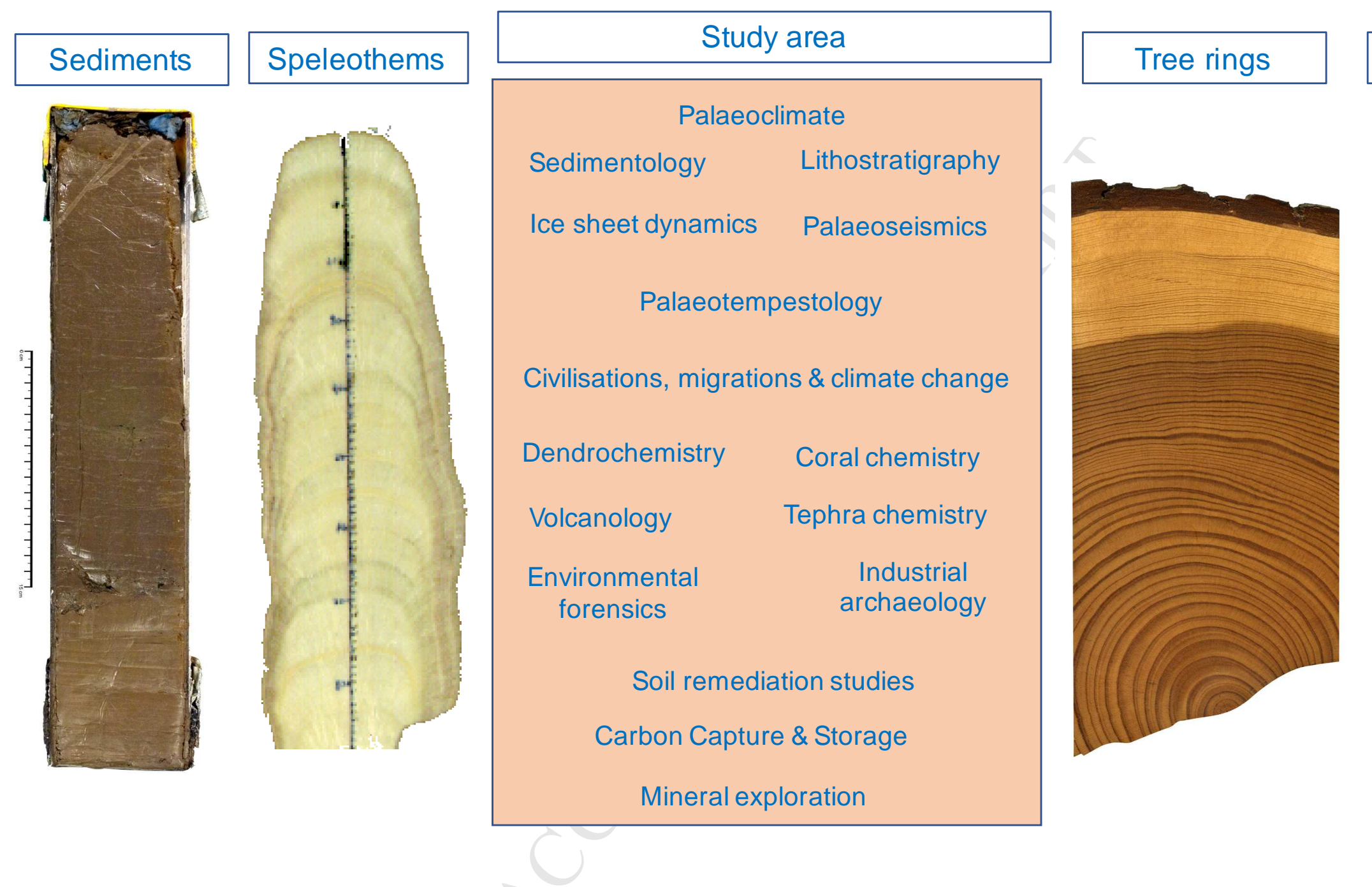

Figure 1: Study areas benefiting from XRF core scanners and referred to in this Special Issue (Images from Croudace collection) 


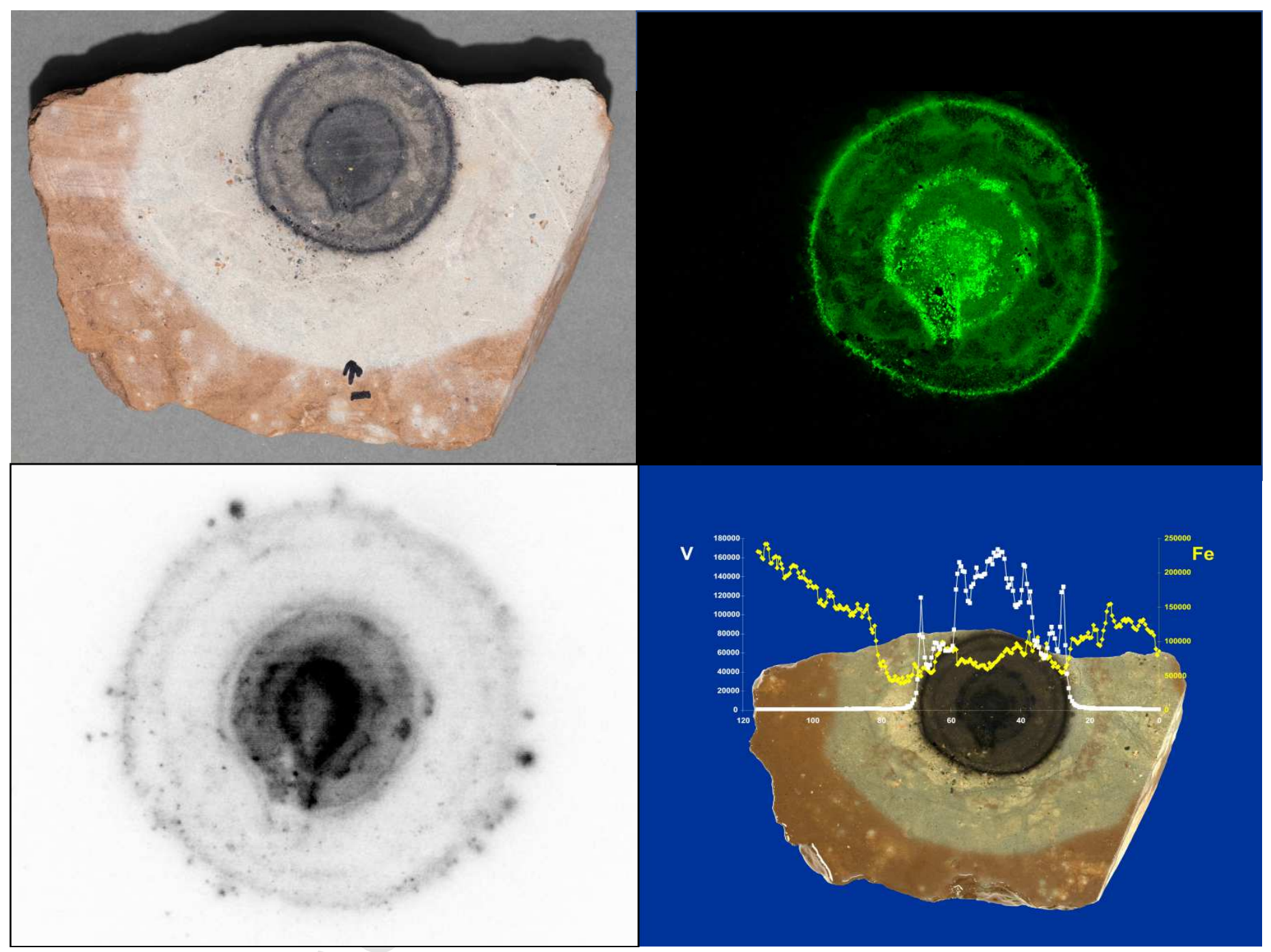

Figure 2: Images from a radioactive sedimentary reduction nodule (Permian, Littleham Cove, UK). The hand specimen is approximately $15 \mathrm{~cm}$ across. The images (clockwise from top left) show a photograph of a cut specimen, a vanadium (V) X-ray map (Bruker M4 Tornado $\mu$ XRF system), V and Fe line scans along the equatorial axis (Itrax) and an autoradiograph (acquired over 2 days using a phosphor plate) revealing the uranium distribution. All images from the Croudace collection 
a

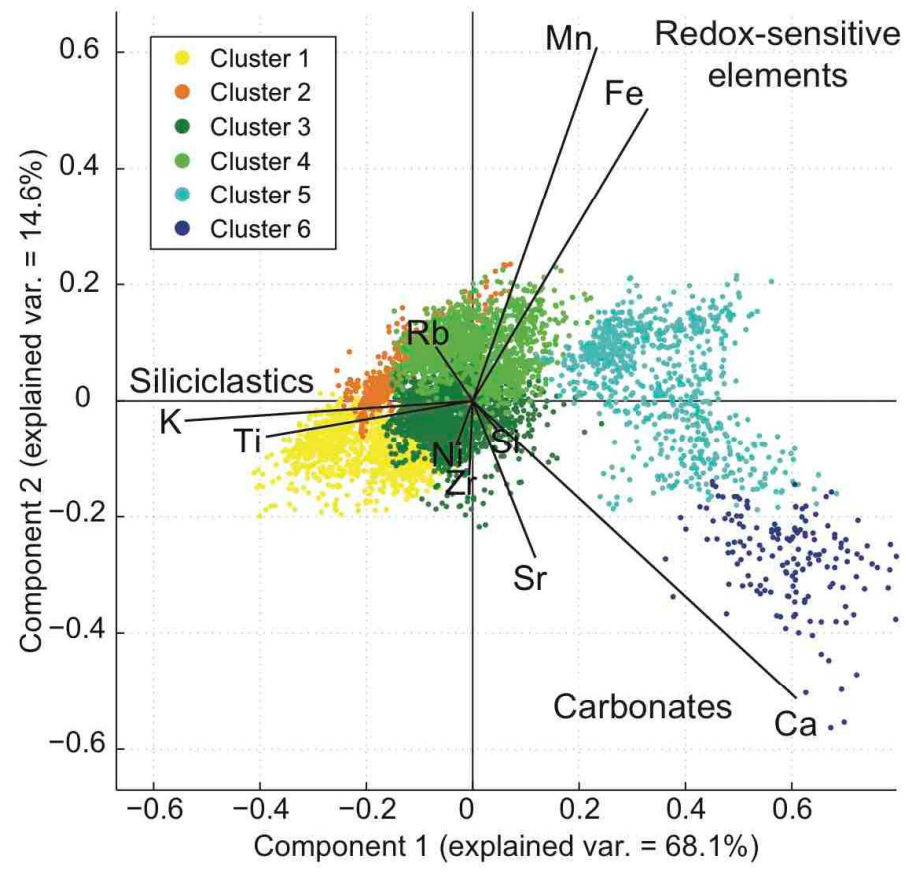

b

- Cluster 3

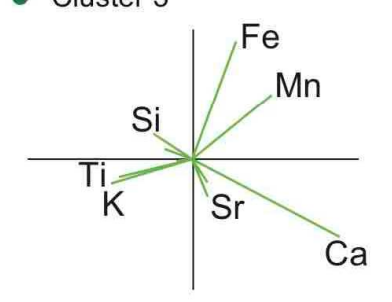

- Cluster 4

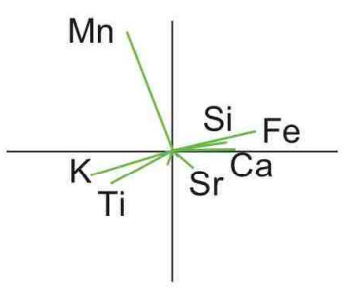

C<smiles>[Mg][Mg][Mg]</smiles>

(Cluster 3)

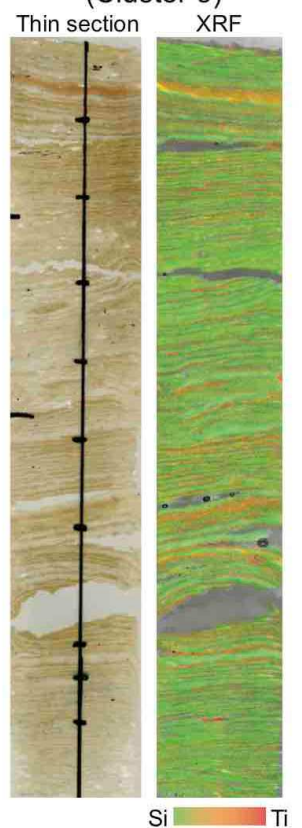

MFM-D4 41-51

(Cluster 4)

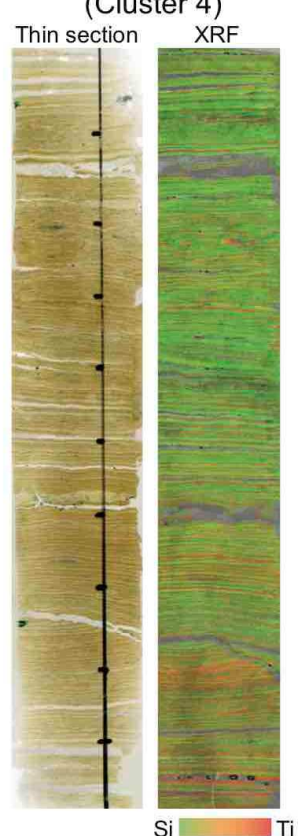

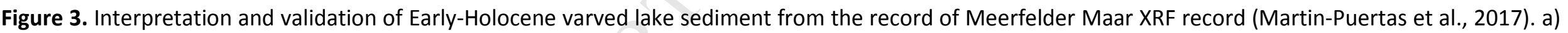

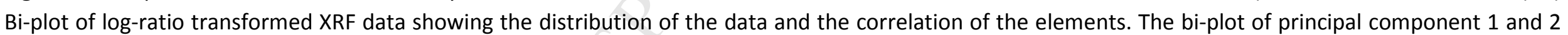

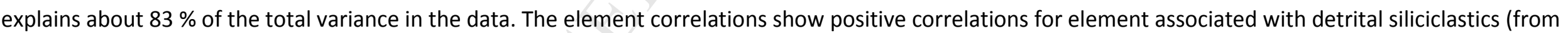

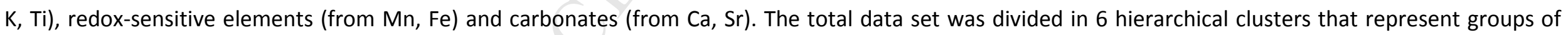

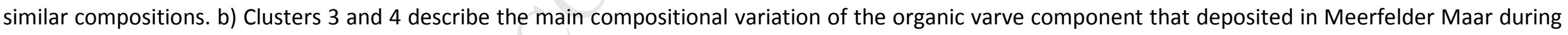

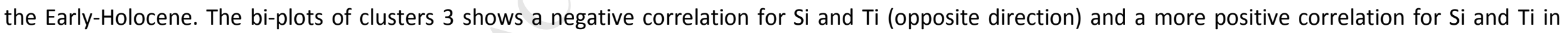

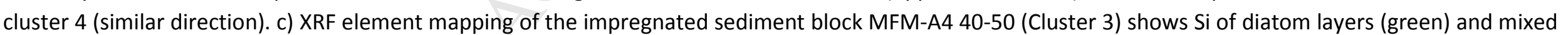

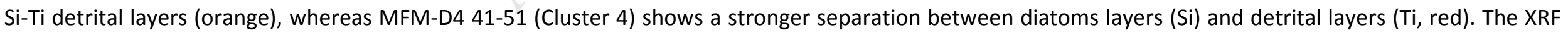
mapping results perfectly link XRF data and thin section microscopic observations. 


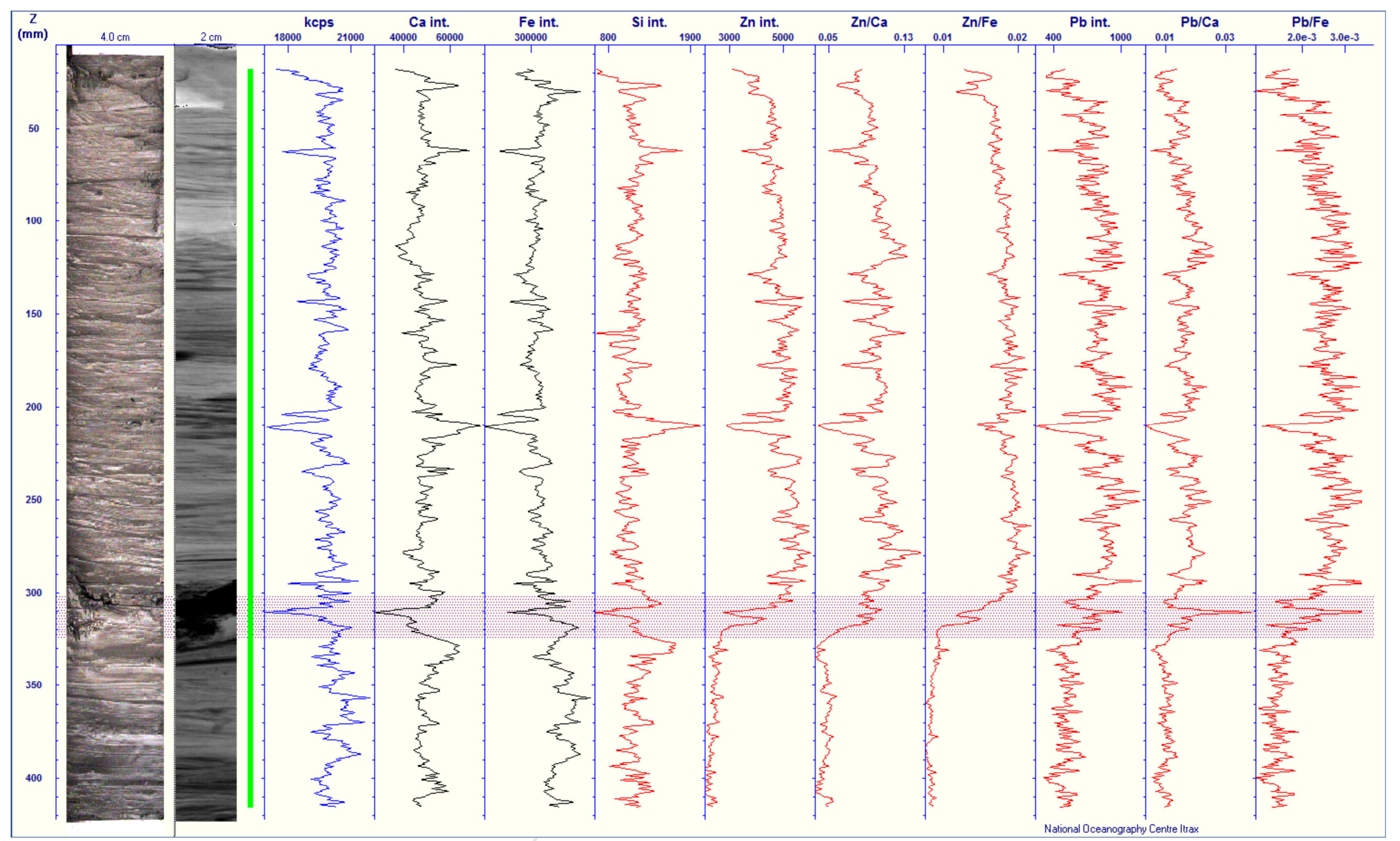

Figure 4: Itrax scan of a sub-tidal sediment core from the Newport Deep (Severn Estuary, UK) with selected elemental profiles (depth scale is in mm). The sharp rise in $\mathrm{Zn}, \mathrm{Zn} / \mathrm{Ca}$ (and $\mathrm{Pb}$ and $\mathrm{Pb} / \mathrm{Ca}$ ) between 350 and $300 \mathrm{~mm}$ depth (stippled) represents the transition from pre-industrial background concentrations to historical industrial inputs. The increase coincides with a distinct pebble layer at $300 \mathrm{~mm}$ depth (visible as the dark zone in the radiograph). The layer is identified as a sedimentary hiatus caused by erosive loss generated by a storm surge, supported by geochemical and radionuclide evidence. This storm layer was the first regional evidence for significant sub-tidal erosion caused by the powerful December $13^{\text {th }} 1981$ storm (Croudace et al. 2012). 


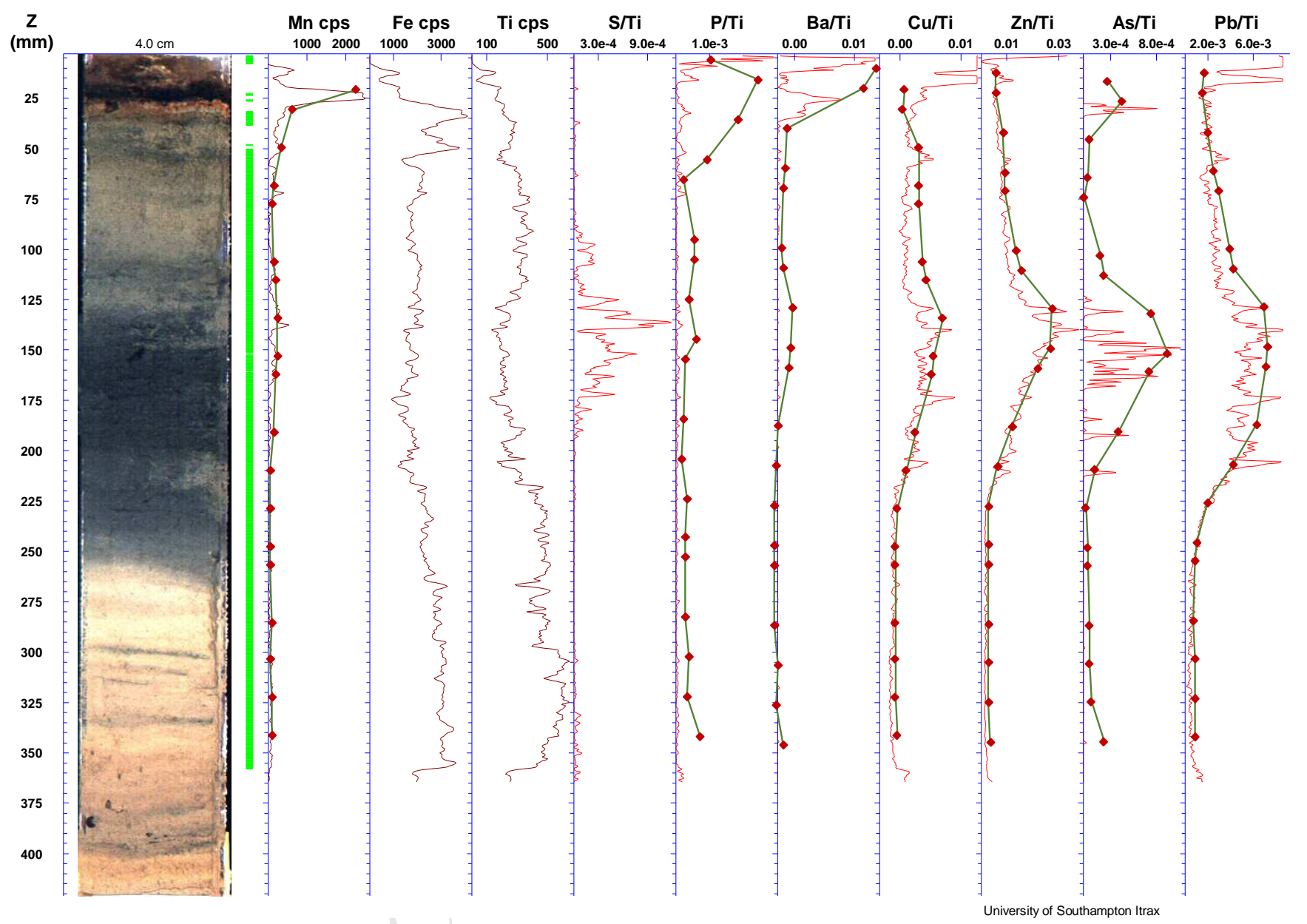

Figure 5: Effects of cultural eutrophication as revealed from elemental distributions in lake core SC57 from the south basin of Windermere (Cumbria, UK). The onset of the organic rich sediment at $\sim 25 \mathrm{~cm}$ depth is equivalent to 1850 and reflects the initial impact of cultural eutrophication in the lake caused by significant increases in population, tourism, pastoral farming and sewage inputs. The red continuous lines represent Itrax data and are compared with quantitative WDXRF data (green continuous line with red filled circles; adapted from Fielding et al, 2019). The WDXRF concentration maxima are Mn 9.6 wt\%, Fe 9.03 wt\%, Ti 0.47 wt\%, P 0.80 wt\%, Ba 2000 ppm, Cu 109 ppm, Zn 1680 ppm, As 81 ppm and Pb 590 ppm. 